\title{
Environmental product declarations entering the building sector: critical reflections based on 5 to 10 years experience in different European countries
}

\author{
Alexander Passer ${ }^{1}$ - Sébastien Lasvaux ${ }^{2,3}$ - Karen Allacker ${ }^{4,5}$ - Dieter De Lathauwer ${ }^{6}$. \\ Carolin Spirinckx $^{7}$ - Bastian Wittstock ${ }^{8,9}$ - Daniel Kellenberger ${ }^{10}$ • Florian Gschösser $^{11}$. \\ Johannes Wall ${ }^{1} \cdot$ Holger Wallbaum ${ }^{12}$
}

Received: 10 March 2015 / Accepted: 28 June 2015 /Published online: 23 July 2015

(C) Springer-Verlag Berlin Heidelberg 2015

\begin{abstract}
Purpose Growing awareness of the environmental performance of construction products and buildings brings about the need for a suitable method to assess their environmental performance. Life cycle assessment (LCA) has become a widely recognised and accepted method to assess the burdens and impacts throughout the life cycle. This LCA-based information may be in the form of environmental product declarations (EPD) or product environmental footprints (PEF), based on reliable and verifiable information. All of these use LCA to quantify and report several environmental impact categories and may also provide additional information. To better understand on the one hand existing EPD programmes (EN 15804) for each country and on the other the recent developments in terms of EU reference document (e.g. PEF), the authors de-
\end{abstract}

Responsible editor: Melissa Bilec

Alexander Passer

alexander.passer@tugraz.at

1 Institute of Technology and Testing of Building Materials, Graz University of Technology, Inffeldgasse 24, 8010 Graz, Austria

2 Environment and Life Cycle Engineering Division, University of Paris-East, Scientific and Technical Centre for Building (CSTB), 24 Rue Joseph Fourier, 38400 Saint Martin d'Hères, France

3 Laboratory of Solar Energetics and Building Physics (LESBAT), University of Applied Sciences of Western Switzerland (HES-SO), Centre St-Roch, Avenue des sports 20, Yverdon-les-Bains 1401, Switzerland

4 European Commission Directorate General-Joint Research Centre, Institute for Environment and Sustainability, Ispra, Italy

5 Present address: Department of Architecture, Faculty of Engineering Science, KU Leuven, Kasteelpark Arenberg 1 box 2431, 3001 Leuven, Belgium cided to write this review paper based on the outcomes of the EPD workshop that was held prior to SB13 Graz conference. Methods This paper presents the state of the art in LCA and an overview of the EPD programmes in five European countries (Austria, Belgium, France, Germany, Switzerland) based on the workshop in the first part and a comprehensive description and comparison of the PEF method and EN 15804 in the second part. In the last part, a general conclusion will wrap up the findings and results will provide a further outlook on future activities.

Results and discussion The high number of EPD programmes underlines the fact that there is obviously a demand for assessments of the environmental performance of construction materials. In the comparison between and experiences of the different countries, it can be seen that more similarities than differences exist. A comparison between PEF and EPD shows

6 Product Policy and Chemical Substances, Federal Public Service of Health, Food Chain Safety and Environment, Victor Horta Square 40, 1060 Brussels, Belgium

7 VITO NV, Unit Smart Energy and Built Environment, Boeretang 200, 2400 Mol, Belgium

8 Fraunhofer Institute for Building Physics IBP, Wankelstrasse 5, 70563 Stuttgart, Germany

9 Present address: thinkstep AG (ehem. PE INTERNATIONAL AG), Hauptstr. 111-115, 70771 Echterdingen, Germany

10 Intep Integrale Planung GmbH, Dufourstrasse 105, 8008 Zürich, Switzerland

11 University of Innsbruck, Technikerstraße 13, 6020 Innsbruck, Austria

12 Chalmers University of Technology, Sven Hultins gata 8, 412 96 Göteborg, Sweden 
differences, e.g. LCIA impact categories and recycling methodology.

Conclusions Independent of raising awareness of the construction material environmental performance, the existence of so many environmental claims calls for clarification and harmonisation. Additionally, construction materials being assessed in the voluntary approaches have to follow the harmonised approach following the principles of the European Construction Products Regulation (regulated) not to foster barriers of trade. The authors therefore highly appreciate the most recent activities of the sustainability of construction works (CEN/ TC 350 committee http://portailgroupe.afnor.fr/public espacenormalisation/CENTC350/index.html) currently working on these issues at the EU level. Finally, the LCA community is further encouraged to increase the background life cycle inventory data and life cycle inventory modelling as well as the meaningfulness of certain environmental impact categories, such as toxicity, land use, biodiversity and resource usage.

Keywords Building certification - Environmental product declaration (EPD) · Life cycle assessment (LCA) · Product environmental footprint (PEF)

\section{Introduction: state of the art of methods for the assessment of the environmental performance of construction products}

Growing awareness of the environmental performance of construction products and buildings brings about the need for a suitable method to assess their environmental performance (Haapio and Viitaniemi 2008; Nemry et al. 2010; Braune and Wittstock 2011; Wallhagen and Glaumann 2011; Passer et al. 2012; Earls 2013; Wallhagen et al. 2013) and to provide proper assistance for applying this information for further use in rising initiatives in the field of building certification. Life cycle assessment (LCA) has become a widely recognised and accepted method to assess the burdens and impacts throughout the life cycle (Haapio and Viitaniemi 2008; Braune and Wittstock 2011; Passer et al. 2012; Lasvaux et al. 2014a; WSB 2014; Passer et al. 2015; Frischknecht et al. 2015). This LCA-based information may be in the form of environmental product declarations (EPD) and product environmental footprints (PEF), based on reliable and verifiable information. All of these use LCA to quantify and report one or more environmental impact categories and may also provide additional information (Allacker 2012).

Authors who assessed consistency across different key aspects of the published product category rules (PCRs), EPDs, and other schemes (with different requirements) state a lack of consistency (Subramanian et al. 2012), or show substantial variations within two versions of an EPD (Ingwersen and Stevenson 2012; Modahl et al. 2012). Whereas Subramanian et al. (2012) indicate the disparities between PCRs ranging from broad differences in scope, system boundaries and impacts addressed (e.g. multi-impact vs. carbon footprint only) to specific differences of technical elements, other authors state an urgent need for credible and verifiable information (Ingwersen and Stevenson 2012) caused by a growing demand for EPDs and related requirements laid down in PCRs.

Recently, several standards and guidance documents have been published, including ISO 14025 (CEN 2014), ISO 21930 (ISO 2007), EN TR 15941 (CEN 2009), EN 15643-1 (CEN 2010), PAS 2050 (BSI 2011), ISO 14067 (ISO 2012) or the Product Environmental Footprint (PEF) Guide (EC 2013) and the European standard on EPD-EN 15804 (CEN 2013). Each of these standards and guidance documents requires some form of PCRs in order to publish a claim that may be used for the purpose of comparison or comparative assertion. However, it has been acknowledged in various expert foraas mentioned above - that the majority of these standards do not provide sufficient guidance to support the creation of consistent PCRs. Ingwersen and Subramanian (2013) state that apart from the European standard for PCRs in the construction sector EN 15084+A1 (CEN 2013)-which will now allow the further development of EPDs - and some recent but limited efforts amongst programme operators to sign a memorandum of understanding agreements (Del Borghi 2012), there has also been an insufficient level of coordination amongst programme operators to develop and align PCRs. Del Borghi states that the lack of a global PCR database with participation of all programme operators who create PCRs has exacerbated the situation because existing PCRs are often not easily discovered, and this has resulted in a sporadic and uncoordinated process of PCR development that is inconsistent and sometimes unnecessarily duplicative. According to Del Borghi, the legitimacy of product environmental claims/EPDs is jeopardised by the increasing costs and time needed to develop PCRs. This can lead to trade barriers on the EU market, which should be avoided following the aim of the Construction Products Regulation (CPR, (EC 2011)) to remove technical barriers to trade in the field of construction products in order to enhance their free movement in the internal market. ${ }^{1}$

To better link EPD development and their implementation in the European member states, the idea of organising a special forum to address these issues was launched and took place at the Sustainable Building conference in Graz (SB13 Graz) ${ }^{2}$ following other recent activities (Ingwersen et al. 2011; Baitz et al. 2012; Del Borghi 2012; Ingwersen and Subramanian 2013; Lasvaux et al. 2014a). The main goal of the workshop was the presentation and discussion of the existing approaches for EPDs in the building sector followed by discussion amongst the invited experts. The workshop furthermore aimed

\footnotetext{
${ }^{1}$ (1) OJ L 88, 4.4.2011, p. 5 (EC 2011).

2 http://www.sb13.org; Full Papers (ISBN 978-3-85125-301-6): http://dx. medra.org/10.3217/978-3-85125-301-6
} 
at contributing to raising awareness about environmental issues of construction products and their contribution towards building certification systems.

Based on the workshop, the authors decided to write a comprehensive scientific paper based on the questions raised. This paper therefore presents the state of the art in life cyclebased information and an overview of the EPD programmes in five European countries in the first part and a comprehensive description and comparison of the EC PEF method and the EN 15804 in the second part. In the last part, a general conclusion will wrap up the overall findings (based on the discussions of the workshop) and results will provide a further outlook on future activities.

\section{Situation report in European countries}

\subsection{EPDs}

On a European level, there are various definitions, e.g. EN ISO 14025, EN 15804 and guidelines as well as the the European CPR. Following the EN 15978:2012, an approach to applying EPDs in building construction and civil engineering works is presented. These guidelines have been applied in the European member states during the past few years.

EPDs state the environmental performance of construction products and services, based on reliable and verifiable information. They will be essential for the assessment of the environmental performance of buildings in the near future. The relevance of EPDs based on the standard EN 15804 and ISO 14025 might increase in the near future as the European CPR mentions EPDs as a possible mean to assess the sustainable use of natural resources and the impacts of construction works on the environment. However, the CPR does not explicitly refer to EN 15804, and the EPD reference is made in the introduction of the CPR, not in the articles. How Basic Requirements ${ }^{3} 7$ has to be dealt with is not yet clear and currently under discussion. Furthermore, the publication of EN 15804 represents a harmonised base for the implementation of EPDs in building construction and civil engineering works.

So far worldwide, more than 28 EPD programmes referring to ISO 14025 exist, providing more than 2256 PCR documents and more than 3600 EPDs (Del Borghi 2012; Hunsager et al. 2014). Table 1 shows an updated compilation of the main existing programmes for EPDs based on Table 1 in Hunsager et al. (2014). In the next part, we focus on five different EPD programmes with a detailed understanding in order to find

\footnotetext{
${ }^{3} \mathrm{BR}$... Basic requirements for construction works no. 7: sustainable use of natural resource, (EC 2011)
}

main criteria for improving harmonisation of all EPD programmes.

\subsubsection{Current situation in Austria}

Due to the Austrian building industry's growing interest in environmental product declarations, a group of Austrian experts from science, research and development as well as industry started to develop basic documents and general programme guidelines in compliance with the standard guidelines EN 15804 and ISO14025 in July 2011.

Based on these basic documents, in July 2013, the Austrian Bau-EPD GmbH (Bau EPD Ltd.) was founded by the Austrian Sustainable Building Platform (ASBP), which has been formed by the two leading Austrian associations for sustainable building, the Austrian Sustainable Building Council (ÖGNB) and the Austrian Green Building Council (ÖGNI). The expert group of the initial period became the PCR advisory board when the Austrian EPD programme was officially founded.

Directly after its foundation, the Austrian Bau-EPD GmbH applied for membership in the European ECO Platform and was initially accepted as an emerging member. Due to the first upcoming EPDs, PCR documents were developed and verified.

Before the publication of the first EPD, the PCR advisory board decided that not only EPD verifiers but also EPD (LCA) practitioners need to register and fulfil specific requirements. Furthermore, it was defined that one institution can register either as EPD practitioner or verifier.

Finally, in May 2014, the first Austrian EPD was published. In October 2014, the so-far six Austrian EPDs published were authorised to place the ECO Platform emblem on their covers, i.e. the Austrian EPD programme finally fulfilled all requirements of the ECO Platform and is now part of the European EPD harmonisation progress as an "established member" of the ECO Platform. However, representatives of the Bau-EPD GmbH have participated in the working groups of the ECO Platform since the application for the membership.

Due to the fact that data from EPDs of the Austrian EPD programme are entered into the Austrian baubook database and the German oekobau.dat, EPDs can apply ecoinvent and/or GaBi datasets (depending on whether the client wants to enter his data in one or both databases) for the performance of the LCA.

The Austrian Bau EPD GmbH organises frequent Workshops for its EPD verifiers and practitioners in order to keep them up to date regarding new developments on the EPD sector.

\subsubsection{Current situation in Belgium}

The Belgian policy with a focus on the LCA approach is mostly driven by the Federal Public Service and the Flemish 
Table 1 Compilation of EPD programmes

\begin{tabular}{|c|c|c|}
\hline $\begin{array}{l}\text { Programme } \\
\text { short }\end{array}$ & Operator name & Web page \\
\hline ADEME* & $\begin{array}{l}\text { Agence de l'Environnement et de la Maîtrise de l'Energie (French Environmental } \\
\text { and Energy Agency) + AFNOR French Standard }\end{array}$ & $\begin{array}{l}\text { www.developpement-durable.gouv.fr/- } \\
\text { Experimentation-de-1-affichage, } 4303-. h t m l\end{array}$ \\
\hline ASTM & ASTM International & www.astm.org/EPDs.htm \\
\hline $\begin{array}{l}\text { BAU- } \\
\text { EPD* }\end{array}$ & Bau EPD GmbH & www.bau-epd.at \\
\hline BRE* & BRE Global & www.greenbooklive.com \\
\hline CEPI & Confederation of European Paper Industries & www.paperpfcr.eu \\
\hline CLF & Carbon Leadership Forum & www.carbonleadershipforum.org \\
\hline DAPc* & $\begin{array}{l}\text { Sistema Declaraciones Ambientales de Productos por la construcción (EPD System } \\
\text { for the Construction sector) }\end{array}$ & www.csostenible.net/index.php/es/sistema_dapc \\
\hline EAA & European Aluminium Association & www.alueurope.eu \\
\hline ecospec & Ecospecifier & www.GlobalGreenTag.com \\
\hline EDF & Environmental Development Foundation & www.edf.org.tw \\
\hline FDES* & $\begin{array}{l}\text { Fiches de Déclaration Environnementale et Sanitaire (Environmental and Health } \\
\text { Declaration Sheets) + AFNOR French Standard }\end{array}$ & www.inies.fr \\
\hline FP & FP Innovations & www.forintek.ca \\
\hline IBU* & Institut Bauen und Umwelt e.V. (Institute for Construction and Environment) & www.bau-umwelt.de \\
\hline ICC-ES & ICC Evaluation Services & www.icc-es.org/ep \\
\hline IES* & International EPD System & www.environdec.com \\
\hline Ift & ift Rosenheim & www.ift-rosenheim.de \\
\hline JEMAI & Japanese Environmental Management Association of Industry & www.ecoleaf-jemai.jp \\
\hline KEITI & Korean Environmental Institute for Technology and Information & www.edp.or.kr \\
\hline MVD & Danks Standard (Danish Standard) & www.mvd.dk \\
\hline $\mathrm{NEF}^{*}$ & Næringslivets miljøstiftelse EPD Norge (Norwegian EPD Foundation) & www.epd-norge.no \\
\hline NRMCA & National Ready Mixed Concrete Association & www.nmrca.org/sustainability/EPDProgram/ \\
\hline NSF & NSF International & www.nsf.org \\
\hline PE & PlasticsEurope & www.plasticseurope.org \\
\hline PEP* & PEP ecopassport & www.pep-ecopassport.org \\
\hline SCS & SCS Global Services & www.scscertified.com \\
\hline TGS & The Green Standard & www.thegreenstandard.org \\
\hline UL & UL Environment & www.ul.com \\
\hline
\end{tabular}

From the authors' perspective, not all of these programmes are necessarily compliant with the programme operator requirements in ISO 14025 . To the best of our knowledge, these programmes (marked with *) are ISO 14025 compliant, others may be compliant as well

Waste Agency OVAM, in collaboration with the Brussels Environmental Administration (IBGE-BIM) and the Walloon Region ${ }^{4}$ and supported by the Belgian Construction Products Producers (BMP-PMC).

There is no private EPD programme operator in Belgium. Instead, the Federal Public Administration of Health and Environment has prepared a legislative document (Royal Decree) which lays down the rules for the uptake of specific EPDs in a federal database. This database will be used by the regions for their building assessment tool MMG (see further). Manufacturers are free to submit EPDs to this national database. Besides

\footnotetext{
${ }^{4}$ All three regions also have other policies to stimulate sustainable construction.
}

this product-building approach, the Royal Decree also contains a measure against greenwashing. If a manufacturer decides to put an environmental claim on his product, he is obliged to make an EPD publically available in the national database from 2015 on.

The Royal Decree refers to the EN 15804 yet includes an article that ensures that from 2017 on also module A4, C and $\mathrm{D}$ become mandatory, as well as the whole set of environmental indicators of the EC PEF method for reasons of having a robust set of indicators. Regarding the background database used for the LCA, the Decree is open, but the federal database will request transparent information about which database has been used.

In 2015, the Belgium federal administration will start the development of rules for the verification and acceptance of 
PCRs, implementing the general stipulations in the Royal Decree. Belgium strives as much as possible towards mutual recognition. For cradle to gate, this will pose few problems (as it does not matter where a production site is located), but for the part gate to grave, the relevance for the Belgian situation should be verified (transport distances, incineration and landfill scenarios, climatic conditions influencing maintenance, etc.). Belgium will try to establish a system where verifiers can register, including an acceptance procedure. By doing this, the verifiers of other programme operators will have the opportunity to include a verification for Belgium if desired by their client. This will lead to a considerable cost reduction for the manufacturer who will then only need one verification process.

Another Decree asks for a very low fee for inclusion of the EPD in the national database. This fee will be put in a fund comanaged by the industry and the administration. The validity of the EPDs is according to the EN 15804.

EPD use in building labelling/certification schemes:

The Flemish administration is taking several steps in order to come to an environmental performance (complementary to an energy performance) based on the LCA approach. This environmental performance shall be calculated in a way that reflects reality as correctly as possible to avoid market distortions. But at the same time, it shall be easily accessible and user friendly for architects and other stakeholders. Both comprehensiveness and readability are hence important issues. In consequence, all relevant environmental indicators should be taken into account but aggregation of this comprehensive set of indicators into a single score is equally important for the final decision makers (e.g. designers). The methodology has been developed and is now being fine-tuned (Allacker 2012). Based on this methodology, a tool for architects will be developed in the next few years.

One of the next steps is the collection of data - which will come from manufacturers - in the national database (see also previous section). This database will be the only entry to the calculation tool for environmental performance, with attention paid to mutual recognition and with an explicit wish to shift this database to the EU level to facilitate the data submission by internationally active companies. In a later stage, the setting of benchmarks and eventually threshold levels at the building (element) level should follow.

Once the environmental performance tool is operational, it could be inserted into existing building rating schemes (e.g. BREEAM or LEED) to assess the material and energy issues in a consistent and integrated way and to avoid as such the subjective weighting of these two issues. The replacement of current qualitative assessments by a quantitative LCA-based approach seems preferred from a scientific point of view and seems hence an important step to improve existing building rating schemes. The scope of LCA is clearly more restricted than the scope in current sustainability certification schemes.
If the above approach is followed, it needs to be further investigated if issues not addressed by the LCA approach (e.g. direct health effects of indoor air emissions to the inhabitants) needs to be added by using different quantitative methods.

\subsubsection{Current situation in Germany}

In Germany, the first EPD was published in 2005, representing unlaminated rockwool of Deutsche Rockwool Mineralwoll GmbH \& Co. OHG. Since then, strong developments have taken place towards a wide acceptance of EPDs as a feasible communication format for environmental claims.

The initial and most relevant EPD programme operator is the "Institut Bauen und Umwelt e.V."-IBU, a non-profit NGO with more than 200 construction product manufacturers as members. IBU is the German member of the European ECO Platform ${ }^{5}$ and adopted EN 15804 into IBU's programme rules in 2011. Today, IBU holds more than 700 EPDs with 80 \% being EN 15804 compliant.

IBU as an independent organisation is headed by an elected board, and the EPD programme operation is executed by the IBU office. IBU's expert panel ("Sachverständigenrat", SVR) assures compliance with EN 15804, resolves any methodological or rule-defining issues and appoints independent verifiers who review EPDs and associated background reports in compliance with a defined set of criteria.

EN 15804 has been adopted as national standard (DIN EN 15804) without national annexes, and IBU brings EN 15804 rules into application by specifying EPD rules in two separate PCR sections. IBU's PCR part A covers a set of rules that is common to all EPDs across all product categories. IBU's PCR part B documents are specific to individual product categories.

In Germany, EPDs are recognised as feasible communication format by the two major building certification systems, DGNB ("Deutsche Gesellschaft für Nachhaltiges Bauen e.V."/German Sustainable Building Council) and BNB ("Bewertungssystem des Bundes für Nachhaltiges Bauen"/ Federal assessment scheme for sustainable construction). In both systems, the use of EPD is encouraged and avoids the application of 10 to $30 \%$ safety margins for data with reduced quality to the obligatory building LCA calculation. Conclusively, after the introduction of these building certification schemes in 2008, a strong development towards wider spread of providing EPDs across the different product categories was observed.

EPDs are collected into the German "Ökobau.dat" public database for building product LCA data that is operated by a subsidiary administration of the Federal Ministry for the Environment, Nature Conservation, Building and Nuclear Safety ("Bundesministerium für Umwelt, Naturschutz, Bau und Reaktorsicherheit", BMUB). The abovementioned safety

\footnotetext{
${ }^{5}$ http://www.eco-platform.org
} 
margins are defined for all generic or EPD datasets that are intended to be added to the Ökobau.dat database (PE INTE RNATIONAL, BBSR 2013) based on each dataset's quality metrics. Through the distribution and provision of EPDs via a single database, planners are encouraged to utilise data that is available from EPDs in their planning procedures.

In conclusion, one may easily come to the understanding that EPDs have found their way from niche application to a broad base, spanning across a wide range of building product categories and suppliers. Frequently, discussions have shifted in recent years from whether a company should have single lighthouse EPDs to how EPD generation can be automated for broad product portfolios.

\subsubsection{Current situation in France}

The national EPD programme in France consists of a publicprivate multi-stakeholder management (INIES 2014, AFNOR 2014a) established since 2001. The goal is to develop a national reference database for the environmental and sanitary impacts of products, equipment and services to be used in the environmental assessment of buildings. This database is called INIES (2014) and is derived from the name of the French EPD programme. At the beginning, the PCR was based on two standards XP P 01-010 and NF P 01-010 from 2004 (AFNOR 2004) where 60 EPDs were released. The programme includes both an environmental and a health production declaration (EHPD) named FDES in French. It includes public authorities with the ministries in charge of Sustainable Development, Housing, Health, Communication and Culture and the Environmental Protection Agency (ADEME), the Scientific and Technical Centre for Buildings (CSTB), the standardisation agency (AFNOR), the construction stakeholders and trade unions including the Construction Products Manufacturers Association (AIMCC), the Building Federation (FFB), the Electrical equipment association (FIEEC), the SME Building Confederation (CAPEB), the Union of architects (UNSFA) and other members including the HQE Association (building labelling scheme (HQE 2014), the association for sustainable residential dwellings (QUALITEL), the National Agency for Improvement of Housing (ANAH), the Federation of consultancy engineering firms (CINOV) and the Social Union for Housing (USH). The EPD programme is associated with the standardisation works conducted at the commission AFNOR P01E "sustainable construction" working group "construction products and buildings".

Concerning the governance of the EPD programme, the owner of the INIES database is the HQE association. The ministry in charge of housing is the chairman of the supervising committee, the AFNOR being the secretary. The AIMCC the is chairman of the technical committee while the CSTB is the secretary. Concerning the other aspects, the AFNOR is responsible of the verification programme and CSTB is responsible for the IT development of the database. Finally, a user committee includes stakeholders responsible of the online declaration of EPDs, users of EPDs (e.g. developers of building-level LCA tools), editors of LCA software and verifiers of EPDs.

The French EPD programme is now in line with the NF EN $15804+\mathrm{A} 1$ and XP P01-064/CN, a national appendix to the European standard (AFNOR 2014b). The national appendix has stringent requirements including toxicity and ecotoxicity indicators and sanitary and comfort requirements amongst others to keep the former NF P 01-010 requirements.

Next to the voluntary aspects of EPDs, a new regulation (JORF 2013a, b) also exists. Since 1 January 2014, a decree on EPDs for construction products states that if a manufacturer (or anyone who introduces a product to the market) wants to make a product's environmental claim or communicate about a product's environmental aspects, an EPD has to be registered in the national database of the regulation project (METL 2014). The decree is also based upon the NF EN 15804+A1 and XP P 01-064/CN (AFNOR 2014b). EPDs have to be stored in the regulated database and can be transferred to the INIES database for use in building labelling schemes (e.g. in $\mathrm{HQE}$ ). It is required to provide a cradle-to-grave EPD to comply with the decree. A specific rule in the decree also details further requirements for a group of manufacturers' EPD to ensure a limited variability amongst the averaged producers. From 1 July 2017, the decree will come into force for technical equipment (incl. electrical, electronic and HVAC equipment) (AFNOR 2014c).

Concerning the technical calculation rules, all background databases which comply with NF EN 15804+A1, XP P 01064/CN and EN TR 15941 can be used for the French EPDs (INIES). The EPD should be updated every 5 years or before if significant changes occurred in the product's manufacturing process. So far, more than 1500 EPDs covering more than 27, 000 commercial references are available in the database (INIES 2014). Around $80 \%$ of them are single manufacturer's EPDs and $20 \%$ group of manufacturer's EPD. As EPDs are now available for the different components of a building, they can be used in building LCA studies through XML export of the database to building-level LCA tools.

The verification process of EPDs, managed by AFNOR, started in 2006. The verification programme includes a recognition procedure for verifiers' competences including an examination to certify the competences of verifiers (INIES 2014). Up to now, 12 verifiers have been approved for a 3-year period. ${ }^{6}$ INIES is active at the EU level through the participation to the ECO Platform works. In that context, the checklist for verification of EPDs defined at the EU level has now been translated

\footnotetext{
${ }^{6}$ List of verifiers accessible online: www.afnor.org/content/download/19100/ 142779
} 
into the programme. According to the regulation, the verification of EPDs will become compulsory from 2017.

EPDs are also being used in labelling schemes (e.g. HQE) and in building LCA tools (e.g. ELODIE). A 4-year national experiment (HQE performance pilot test) concerning the LCA of 110 new buildings used all the EPDs available to date in INIES to determine LCA reference values at the building level for the embodied impacts (related to the life cycle of products) as well as for the operational impacts (HQE 2014). Such an experiment is a first step before the launch of the new LCAbased label HQE performance.

\subsubsection{Current situation in Switzerland}

A study done a couple of years ago with a survey amongst Swiss product manufacturers showed that there was "no need" for an EPD programme. ${ }^{7}$ Therefore, no Swiss EPD programme has been put in place up to now. Nevertheless, different EPDs of Swiss manufacturers have been published (e.g. Pavatex, Isover). These are mainly manufacturers which are exporting their products to the EU (e.g. Pavatex) and/or want to present the environmental advantages on an objective basis (e.g. Isover, Cemsuisse). In the near future, the freely available LCA building product list "Ökobilanzdaten im Baubereich 2009/1" (Plattform Ökobilanzdaten im Baubereich (2014)) will allow an uptake of product-specific data from EPDs. Therefore, additional to the impacts required in EN 15804:2012, the ecological scarcity (Frischknecht et al. 2009), the non-renewable and total primary energy have to be provided. The data also has to fulfil the quality criteria of the LCA building product list. Furthermore, it forms the basis for all building certification schemes and standards in Switzerland (MINERGIE-A, MINERGIE (-P/-A)-ECO, 2000-WDevelopment Site, Standard for Sustainable Construction and for the moment DGNB/SGNI Switzerland) and is therefore of high importance.

Despite the decision that there is no need for a national EPD programme in Switzerland, several organisations are discussing or are even working on a programme. The work and discussions include a programme which could be carried by one specific building material association and another which could be based on a material-neutral organisation. The programme then could either be in collaboration with an existing European programme or be developed specifically for Switzerland. To be successful in a small market like Switzerland, the programme needs to be self-supporting without being unaffordable for the manufacturers and it should attract more than just one industry sector.

\footnotetext{
${ }^{7}$ Ergebnisse der Umfrage EPD Programm Schweiz, ESU, Rolf Frischknecht, 30.11.2011; http://www.bbl.admin.ch
}

\subsubsection{Summary EPD}

In the comparison between and experiences of the different countries, it can be seen that more similarities than differences exist. Table 2 presents a comprehensive comparison of the differences in the EPD approaches. Whereas all EPDprogrammes are based on EN 15804, some countries are currently working on (additional) national appendix of EN 15804 because of national particularities or legislations.

From the authors' perspective, a harmonisation could be reached only at the EU level by the development of general guidelines regarding scheme management and the application of LCA and through the mutual recognition amongst the different schemes. Currently, the Ecoplatform serves as an excellent source for harmonisation activities for verification procedures and certification of verifiers, providing a list of criteria to check. However, only a limited number of scientific papers have evaluated the influence of the use of different generic databases which can result in different results on the EPD level.

\subsection{Description of the PEF method and PEFCRs}

To come up to the identified need for harmonisation of LCA studies and LCA-based environmental claims for all kind of products, the European Commission (EC) developed additional to the CEN/TC350 framework and the EN 15804 the PEF and Organisation Environmental Footprint (OEF) methods. Both methods have been communicated and recommended by the European Commission in April 2013 (EC 2013). In this paper, only the EC PEF method will be discussed. A more detailed elaboration on the EC OEF method can be found in Pelletier et al. (2014).

The EC PEF method supports multi-criteria assessment of the environmental performance of a product (i.e. a good or service) throughout its life cycle. The EC PEF method accommodates a broad suite of relevant environmental performance indicators in order to decrease the probability of burden shifting. The aim of the EC PEF method is furthermore to guarantee consistent and reproducible results. In order to enable comparisons and comparative assertions, the EC PEF method also includes guidelines on how to develop PEF category rules - comparable to the PCRs-for specific product groups. The EC PEF method is a general method which is valid for all kind of products, amongst which number also construction products and buildings. When PEF category rules (PEFCRs) for construction products are developed, these will need to be in line with the EC PEF method. Some deviations are possible within PEFCRs, such as a more limited number of impact categories (i.e. only the relevant ones), life cycle stages and/or processes which can be excluded when proven irrelevant. 
Table 2 Comparison of national EPD programmes

\begin{tabular}{|c|c|c|c|c|c|}
\hline & Austria & Belgium & France & Germany & Switzerland \\
\hline $\begin{array}{l}\text { Standards used for } \\
\text { EPDs (PCRs, rules) }\end{array}$ & $\begin{array}{l}\text { ÖN EN } 15804, \text { ÖN EN } \\
\text { ISO } 14025\end{array}$ & $\begin{array}{l}\text { The royal Dutch decree refers to } \\
\text { the EN } \\
15804+\mathrm{A} 4, \mathrm{C} \text { and D }\end{array}$ & $\begin{array}{l}\text { NF EN ISO } 14025 \text { NF EN 15804+ } \\
\text { A1 NF P 01- } \\
\text { 064/CN Decree on EPD }{ }^{a}\end{array}$ & $\begin{array}{l}\text { DIN EN ISO 14025, DIN } \\
\text { EN 15804+A1 }\end{array}$ & SN EN 15804 \\
\hline $\begin{array}{l}\text { Specific PCRs for } \\
\text { product } \\
\text { category (e.g. } \\
\text { product TC...) }\end{array}$ & $\begin{array}{l}96 \text { different PCRs, } \\
\text { number growing }\end{array}$ & $\begin{array}{l}\text { Development of rules for } \\
\text { verification and } \\
\text { the acceptance of PCRs will } \\
\text { start } \\
\text { by the end of } 2014\end{array}$ & $\begin{array}{l}\text { No PSR but national trade unions } \\
\text { have developed } \\
\text { specific rules for the } \\
\text { EPDs of their products } \\
\text { family. Product TC PSR } \\
\text { according to NF EN } \\
15804 \text { should replace the } \\
\text { previous rules }\end{array}$ & $\begin{array}{l}\text { Approx. } 100 \text { EN 15804- } \\
\text { compliant PCRs in } \\
\text { the IBU system, number } \\
\text { growing }\end{array}$ & $\begin{array}{l}\text { No Swiss specific PCRs } \\
\text { existing yet }\end{array}$ \\
\hline $\begin{array}{l}\text { Duration of EPD } \\
\text { scheme } \\
\text { development }\end{array}$ & $\begin{array}{l}\text { About } 3 \text { months from } \\
\text { submission } \\
\text { to publication of EPD }\end{array}$ & & $\begin{array}{l}\text { EPD program established in } 2004 \\
\text { in France, } \\
\text { currently updated according EN } \\
15804\end{array}$ & & $\begin{array}{l}\text { No Swiss EPD scheme } \\
\text { existing yet }\end{array}$ \\
\hline $\begin{array}{l}\text { National specific rules } \\
\text { (e.g. national } \\
\text { appendix of EN } \\
15804 \text { in France) }\end{array}$ & $\begin{array}{l}\text { National appendix of EN } \\
15804 \text { in } \\
\text { development }\end{array}$ & $\begin{array}{l}\text { National appendix of EN } 15804 \\
\text { in development }\end{array}$ & $\begin{array}{l}\text { National appendix NF P01-064/CN } \\
\text { with especially } \\
\text { sanitary and comfort aspects to } \\
\text { keep the same } \\
\text { level of completeness as the first } \\
\text { generation of EPDs }\end{array}$ & $\begin{array}{l}\text { No national annex to EN } \\
\text { 15804, specific rules } \\
\text { defined in IBU's PCR } \\
\text { part A (applicable to } \\
\text { all EPDs) and product } \\
\text { category-specific } \\
\text { PCR part B documents }\end{array}$ & $\begin{array}{l}\text { National appendix SN } \\
\text { EN 15804: } \\
\text { addition to "data } \\
\text { quality" and } \\
\text { "disposal phase" }\end{array}$ \\
\hline $\begin{array}{l}\text { Background database } \\
\text { used for the LCA }\end{array}$ & Ecoinvent $^{\mathrm{b}}$ and $\mathrm{GaBi}^{\mathrm{c}}$ & $\begin{array}{l}\text { The Royal Decree is open, but } \\
\text { request } \\
\text { transparent information }\end{array}$ & $\begin{array}{l}\text { Available background data in LCA } \\
\text { software } \\
\text { (e.g. ecoinvent, } \mathrm{GaBi} \ldots)\end{array}$ & $\begin{array}{l}\text { GaBi and ecoinvent v2.2 } \\
\text { (limited to non- } \\
\text { German EPDs) }\end{array}$ & Ecoinvent ${ }^{\mathrm{b}}$ version 2.2 \\
\hline $\begin{array}{l}\text { Organisation of the } \\
\text { national EPD } \\
\text { program }\end{array}$ & $\begin{array}{l}\text { Bau } E P D \mathrm{GmbH}^{\mathrm{d}} \text { is a } \\
\text { cooperation } \\
\text { of the Austrian } \\
\text { building } \\
\text { certification systems } \\
\text { ÖGNB } \\
\text { and ÖGNI }\end{array}$ & $\begin{array}{l}\text { OVAM }^{\mathrm{g}} \text { in cooperation with } \\
\text { Brussels Environmental } \\
\text { Administration (IBGE-BIM }{ }^{\mathrm{h}} \text { ) } \\
\text { and Walloon } \\
\text { Region and the Belgian } \\
\text { Construction Products } \\
\text { Producers (BMP-PMC }{ }^{\mathrm{i}} \text { ) } \\
\text { Federal Public } \\
\text { Administration of Health and } \\
\text { Environment } \\
\text { (Royal Decree) }\end{array}$ & $\begin{array}{l}\text { Multi-stakeholders process } \\
\text { involving public authorities, } \\
\text { standardisation agency, CSTB, } \\
\text { construction sectors } \\
\text { associations, the HQE } \\
\text { association and other players } \\
\text { (more information in: www. } \\
\text { inies.fr) }\end{array}$ & $\begin{array}{l}\text { Institut Bauen und Umwelt } \\
\text { (IBU) e.V.: } \\
\text { non-profit non-govern- } \\
\text { mental organization }\end{array}$ & $\begin{array}{l}\text { No Swiss program } \\
\text { existing yet }\end{array}$ \\
\hline $\begin{array}{l}\text { Cost aspects }(\mathrm{EPD}, \\
\text { verification, } \\
\text { registration) }\end{array}$ & $\begin{array}{l}\text { EPD, } 700 \text {; verfification, } \\
€ 1.800 \text { for } \\
\text { EPDs prepared by } \\
\text { registered LCA } \\
\text { practitioners; } € 3.000 \\
\text { for EPDs } \\
\text { prepared by not- } \\
\text { registered LCA } \\
\text { practitioners; yearly } \\
\text { fee, } € 1.200-9.000 \\
\text { depending on } \\
\text { company/association } \\
\text { size }\end{array}$ & $\begin{array}{l}\text { Not defined yet. But a fund co- } \\
\text { managed by the } \\
\text { industry and the administra- } \\
\text { tion }\end{array}$ & $\begin{array}{l}\text { Some aspects are precised in } \\
\text { the presentation of } \\
\text { the Environmental and } \\
\text { Health Product Declaration } \\
\text { (EHPD) program in the fol- } \\
\text { lowing link: } \\
\text { www.afnor.org/content/ } \\
\text { download/62497/691387. } \\
\text { Fees (excl. VAT) } \\
\text { —examination of the } \\
\text { issuer's file, } \\
\text { between } 100 \text { and } 200 € \\
\text { depending on the } \\
\text { number of EPDs; running } \\
\text { costs for the INIES } \\
\text { database, } 100 € \text { per year }\end{array}$ & $\begin{array}{l}\text { Annual costs, first EPD } 800 \\
€ \text {, prices decrease } \\
\text { with growing number of } \\
\text { EPDs to } 100 € \\
\text { per EPD ( } 5 \text { and more } \\
\text { EPDs) verification, } \\
700 € \text { per EPD; label fee, } \\
500 € \text { per EPD; } \\
\text { annual membership for } \\
\text { product manufacturers, } \\
800 \text { to } 9.000 € \text {, depending } \\
\text { on size of } \\
\text { company/association, } \\
\text { non-members have } \\
\text { higher annual declaration } \\
\text { fees }\end{array}$ & $\begin{array}{l}\text { No Swiss program } \\
\text { existing yet }\end{array}$ \\
\hline Verification process & $\begin{array}{l}\text { According to } \\
\text { ecoplatform }\end{array}$ & According to ecoplatform ${ }^{\mathrm{j}}$ & According to ecoplatform ${ }^{j}$ & According to ecoplatform ${ }^{j}$ & $\begin{array}{l}\text { Independent external } \\
\text { declaration }\end{array}$ \\
\hline Certification of verifiers & $\begin{array}{l}\text { Verifiers have to fulfill } \\
\text { specific criteria } \\
\text { according to } \\
\text { requirements of ECO } \\
\text { Platform; registered }\end{array}$ & $\begin{array}{l}\text { Procedure under development - } \\
\text { ECO-platform } \\
\text { will be taken into account }\end{array}$ & $\begin{array}{l}\text { According to ecoplatform }+ \text { exam } \\
\text { to certify the competences } \\
\text { of the verifiers. Verifiers must } \\
\text { have an LCA } \\
\text { and EPD expertise }\end{array}$ & According to ecoplatform ${ }^{\mathrm{j}}$ & $\begin{array}{l}\text { Declaration based on EN } \\
\text { ISO } 14025: 2010\end{array}$ \\
\hline
\end{tabular}


Table 2 (continued)

\begin{tabular}{|c|c|c|c|c|c|}
\hline & Austria & Belgium & France & Germany & Switzerland \\
\hline List of criteria to check & $\begin{array}{l}\text { Verification criteria } \\
\text { based on } \\
\text { requirements of } \\
\text { ecoplatform } \\
\text { i }\end{array}$ & $\begin{array}{l}\text { Verification criteria based on } \\
\text { requirements of ecoplatform }\end{array}$ & $\begin{array}{l}\text { Verification criteria based on } \\
\text { requirements of ecoplatform }\end{array}$ & $\begin{array}{l}\text { Verification criteria based on } \\
\text { requirements } \\
\text { of ecoplatform }^{j}\end{array}$ & Not yet existing \\
\hline $\begin{array}{l}\text { Validity of the EPD } \\
\text { (PCR if relevant) }\end{array}$ & 5 years & 5 years & 5 years & $\mathrm{EPD}, 5$ years; $\mathrm{PCR}, 3$ years & 5 years \\
\hline $\begin{array}{l}\text { EPD use in building } \\
\text { labelling/ } \\
\text { certification schemes }\end{array}$ & $\begin{array}{l}\text { ÖGNB }{ }^{\mathrm{e}} \text { and } \\
\text { klima:aktiv }^{\mathrm{k}} \text { via } \\
\text { baubook }^{\mathrm{l}} \\
\text { ÖGNI }^{\mathrm{f}} \text { via } \\
\text { oekobau.dat }^{\mathrm{m}} \\
\text { (planned) }\end{array}$ & BREEAM $^{\mathrm{n}}$, LEED $^{\circ}$ & $\mathrm{HQE}^{\mathrm{p}}$ & DGNB $^{\mathrm{q}}$ & $\begin{array}{l}\text { MINERGIE-A, MINE } \\
\text { RGIE-(-P/-A)-ECO } \text {, } \\
\text { 2000-Watts- } \\
\text { Development Sites }{ }^{\mathrm{s}} \text {, } \\
\text { SGNI } \\
\text { (DGNB CH) }{ }^{\mathrm{t}}, \text { Stan- } \\
\text { dard for Sustainable }^{\text {Construction SNBS }}\end{array}$ \\
\hline
\end{tabular}

All data refer to the year 2014

${ }^{a}$ Link to the EPD decree, www.legifrance.gouv.fr/affichTexte.do?cidTexte=JORFTEXT000028398471\&categorieLien=id; link to the EPD implementation order, www.legifrance.gouv.fr/affichTexte.do?cidTexte=JORFTEXT000028398569

${ }^{\mathrm{b}}$ www.ecoinvent.org

${ }^{\mathrm{c}}$ www.gabi-software.com

${ }^{\mathrm{d}}$ www.bau-epd.at

e www.oegnb.net

${ }^{f}$ www.ogni.at

${ }^{g}$ www.ovam.be

${ }^{\mathrm{h}}$ www.ibgebim.be

i www.bmpmc.be

${ }^{\mathrm{j}}$ www.ecoplattform.eu

${ }^{\mathrm{k}}$ www.klimaaktiv.at

${ }^{1}$ www.baubook.at

${ }^{\mathrm{m}}$ www.nachhaltigesbauen.de

${ }^{\mathrm{n}}$ www.breeam.uk

${ }^{\circ}$ www.leed.usgbc.com

${ }^{\mathrm{p}}$ www.hqe.fr

${ }^{\mathrm{q}}$ www.dgnb.de

${ }^{\mathrm{r}}$ www.mindergie.ch

${ }^{\mathrm{s}}$ www.2000watt.ch

${ }^{\mathrm{t}}$ www.sgni.ch

u www.snbs.ch

\subsection{Comparison between the EC PEF method and EN 15804}

A comparison between the EC PEF method and EN 15804 shows some differences. It is however important to keep in mind that minor deviations - based on justifications - from the EC PEF method are possible in future PEFCRs for construction products. This is currently being investigated for several construction products within the PEF pilots (European Commission-DG Environment 2014). Before going into a more detailed comparison of both methods, the difference in their goal needs to be stressed. As mentioned before, one of the important goals of the EC PEF method is to enable comparisons of the life cycle environmental impact of products through the development of PEFCRs. This is not the objective of the EN 15804 as the comparison is only relevant at the building level. The latter aims at transparently reporting the environmental impact of a building product for each life cycle stage separately (i.e. environmental impacts need to be communicated for each of the defined modules). This difference in goal hence leads to different methodological choices. A summary of the main differences between both methods is provided in Table 3. The latest version of the EN 15804 (i.e. EN 15804:2012+A1) is used for the comparison, although this version was not available yet at the time of the workshop in September 2013. Table 3 does not provide an exhaustive list 
of differences but is limited to the most crucial ones. Besides these, several other differences are noticeable, such as a different terminology (the EC PEF method proposing new terms compared to ISO 14040 or EN 15804), requirements regarding nomenclature and review and reviewer requirements.

From the comparison of both methods, it becomes clear that both differ on each of the phases in an LCA assessment: goal and scope definition, life cycle inventory, life cycle impact assessment and interpretation of the results.

In order to avoid two different methods to be applied for the calculation of the environmental impact of building products, a harmonisation of the PEFCRs for construction products and the EN 15804 seems crucial. This was also discussed by Lasvaux et al. (2014b). The comparative analysis shows that some major issues need to be aligned to achieve harmonisation. One issue is the set of environmental impact categories considered. If proven that the additional environmental impact categories in the EC PEF method are irrelevant for construction products, these may be excluded in the PEFC Rs for building products. Not all differences can however be eliminated within PEFCRs of construction products, a revision of both the EC PEF method and EN 15804 standard will be necessary if harmonisation is desired. To remain within the issue of impact assessment, an alignment of the impact assessment models (and related indicators) for each of the impact categories is necessary. We refer to Table 2 for the main differences and hence issues which need alignment if harmonisation is striven for.

\section{Discussion and outlook}

The motivation for the workshop at the SB13 Graz as well as for this publication is to be seen in the multitude of currently existing approaches to assess the environmental performance of construction materials and buildings that lead to a lot of confusion in the building industry itself as well as for other stakeholders, such as architects, planners, customers, media and, last but not the least, procurers and policy makers.

This paper tries to shed light on the differences of EPD's, PEF's and the CPR. It provides an overview of the state of the art in currently existing EPD programmes and puts it into relation with other building material assessment-based approaches on the basis of a workshop held at SB13 Graz. In its first part, the paper describes the different approaches, followed by a detailed comparison of five EPD programmes from Austria, Belgium, France, Germany and Switzerland that were presented at the SB13 conference. In the second part, the paper presents an overview of differences in methodologies applied by each of the two assessment approaches. In the last part, the paper concludes with a comparison of the EC PEF method and the EN 15804:2012+A1:2013.
The high number of EPD programmes underlines the fact that there is obviously a demand for assessments of the environmental performance of construction materials. At the same time, it needs to be stated again that a comparison on the product level is very limited in its ability to identify life cycle-wide the most environmentally superior one. Moreover, the CPR and the EN 15978 state that construction materials need to be assessed only on the building level in the context of its application and place, addressing different framework conditions (e.g. functional and technical requirements) amongst others climate, energy supply and transport systems.

Nevertheless, the current trend towards "nearly zero energy buildings" 8 with their goal of reducing the heating demand to nearly zero and providing the remaining demand using renewable energy sources that have already been put into a legislative framework in some regions, e.g. in the European Energy Performance of Buildings Directive or the CPR in BR 6, demands a stronger emphasis on the construction, maintenance and end-of-life phase of buildings and thus, construction materials.

Furthermore, an increasing number of companies are interested in making their efforts visible to the outer world in the form of environmental performance certificates of their products to achieve a competitive advantage. This holds true especially for EPD's that are also often used within building certification systems. As the assessment of sustainability and the comparison of products should only be carried out at a building level, it is vital that the EPD data is implemented in building labelling schemes such as BREEAM, LEED, DGNB, ÖGNB/ÖGNI, HQE or Minergie/SNBS. The latest version of the US Green Building Council's LEED standard, LEED $\mathrm{v} 4$, now gives credit to building projects using products that have EPDs and follows the benchmark set by other systems, such as the German DGNB.

Independent of raising awareness of the construction material environmental performance, the existence of so many environmental claims calls for clarification and harmonisation on the European or at least on a regional level. Harmonisation is needed on the impact categories and assessment models/ indicators, on the system boundaries and service life of products and buildings, on the definition of scenarios (transport, use phase and end-of-life), allocation rules, biogenic carbon emissions, end-of-life approach, data quality requirements, etc. In terms of EPD programmes, the ECO Platform is the first step in this direction. A second harmonisation step is the development of the PEFCRs within the ongoing PEF pilots

\footnotetext{
$\overline{8}$ http://ec.europa.eu/energy/efficiency/buildings/implementation_en.htm

${ }^{9}$ Basic requirement for construction works no. 6 - energy economy and heat retention requires that, construction works must also be energy-efficient, using as little energy as possible during their construction and dismantling."
} 
Table 3 Summary of main differences between the EC PEF method (2013) and the EN 15804:2012+A1:2013

Criteria

EC PEF method (2013)

EN 15804:2012+A1:2013

Resource use and emissions profile/life cycle inventory

Data quality requirements

Strict requirements for PEF studies intended for external communication.

Specific data

Cut-off

Dealing with data gaps

Handling multi-functionality

End-of-life (EoL) allocation

Environmental impact assessment

Number of impact categories

Indicators (and models if mentioned) Indicator
Mandatory for all foreground processes and for background processes, where appropriate.

Only for processes in the background system. When available, sector-specific generic data to be used instead of multi-sector generic data; shall fulfil the data quality requirements; recommended sources provided.

No cutoff allowed.
Any data gaps shall be filled using best available generic or extrapolated data and shall not account for more than $10 \%$ of the overall contribution to each impact category considered based on the initial screening exercise.

Hierarchy:

(1) subdivision or system expansion;

(2) allocation based on a relevant underlying physical relationship;

(3) allocation based on some other relationship.
To be included: until the product is returned to nature as a waste or enters another product's life cycle.

EoL allocation formula is provided based on the 50:50 approach.

Combined approaches where parts of the supply chain are subject to quantitative analysis and others to qualitative descriptions of potential environmental hotspots are also possible.
Data shall be as current as possible (updated within 10 years for generic data and 5 years for specific data); 1-year averaged data to be used; time period shall be 100 years. Technological coverage shall reflect the physical reality.

First choice: specific + average data However, reference is made to CEN TR15941, according to which generic data may also be used to refer to the manufacturer's own process (on site).

May be used for the processes the producer cannot influence; documentation of technological, geographical and timerelated representativeness shall be provided.

$1 \%$ of renewable/non-renewable primary energy usage, $1 \%$ of the total mass input of that unit process. Total of neglected input flows per module shall be a max. of $5 \%$ of energy usage and mass + environmental relevance (i.e. a less than $1 \%$ of mass or energy flow harmful has to be taken into account in the LCI)

In case of insufficient data or data gaps for a unit process, see cutoffs allowed.

Hierarchy:

(1a) avoidance by subdivision;

(1b) subdivision without data available on sub-processes, partitioning reflecting the underlying physical relationship;

(2) allocation based on physical properties when the difference in revenue from the coproducts is low; in all other cases, it shall be based on economic values (exception: material flows carrying specific inherent properties shall always be allocated reflecting the physical flows, irrespective of the allocation chosen for the process).

EoL system boundary: until the end-of-waste state is reached: EoL processing assigned to the product system that generates the waste, further processing may be necessary in order to replace the primary material or fuel input in another product system. Such processes are considered to be beyond the system boundary and are assigned to the optional informative module $\mathrm{D}$.

7

Indicator

Model/method 
Table 3 (continued)

\begin{tabular}{|c|c|c|c|c|}
\hline \multirow{2}{*}{$\begin{array}{l}\text { Criteria } \\
\text { Global warming }\end{array}$} & \multicolumn{2}{|l|}{ EC PEF method (2013) } & \multicolumn{2}{|c|}{ EN 15804:2012+A1:2013 } \\
\hline & kg CO2 eq. & Bern model (IPCC) & kg CO2 eq. & $\begin{array}{l}\text { IPCC/CML v } 4.1 \\
\quad 2012\end{array}$ \\
\hline Ozone depletion & kg CFC-11eq. & EDIP model based on WMO & kg CFC-11 eq. & CML v 4.12012 \\
\hline Ecotoxicity for aquatic fresh water & $\begin{array}{l}\text { CTUe (comparative toxic unit for } \\
\text { ecosystems) }\end{array}$ & USEtox model & - & - \\
\hline Human toxicity-cancer effects & CTUh (comparative toxic unit for & USEtox model & - & - \\
\hline Human toxicity—non-cancer effects & humans) & & - & - \\
\hline $\begin{array}{l}\text { Particulate matter/respiratory } \\
\text { inorganics }\end{array}$ & $\mathrm{kg}$ PM2,5 eq. & RiskPoll model & - & - \\
\hline $\begin{array}{l}\text { Ionising radiation-human health } \\
\text { effects }\end{array}$ & kg U 235 eq. (to air) & Human health effect model & - & - \\
\hline Photochemical ozone formation & kg NMVOC eq. & LOTOS-EUROS model & $\mathrm{kg}$ ethene eq. & CML v 4.12012 \\
\hline Acidification & mol H+ eq. & Accumulated exceedance & kg SO2 eq. & CML v 4.12012 \\
\hline Eutrophication - terrestrial & mol N eq. & model & $\mathrm{kg}(\mathrm{PO} 4)^{3-}$ eq. & CML v 4.12012 \\
\hline Eutrophication-aquatic & Fresh water: kg P eq. marine: $\mathrm{kg} \mathrm{N}$ eq. & EUTREND model & - & - \\
\hline Resource depletion—water & $\begin{array}{l}\mathrm{m}^{3} \text { water use related to local scarcity of } \\
\text { water }\end{array}$ & Swiss ecoscarcity model & - & - \\
\hline $\begin{array}{l}\text { Resource depletion-mineral, } \\
\text { fossil }\end{array}$ & $\mathrm{kg}$ antimony $(\mathrm{Sb})$ eq. & CML2002 model & $\begin{array}{l}\text { MJ, net calorific } \\
\text { value }\end{array}$ & CML v 4.12012 \\
\hline Resource depletion-non-fossil & - & - & $\begin{array}{l}\text { kg antimony }(\mathrm{Sb}) \\
\text { eq. }\end{array}$ & CML v 4.12012 \\
\hline Land use & kg (deficit) & $\begin{array}{l}\text { Soil organic matter (SOM) } \\
\text { model }\end{array}$ & - & - \\
\hline Normalisation & $\begin{array}{l}\text { Not required if applied, methods and resu } \\
\text { "additional environmental information } \\
\text { not be aggregated as this implicitly app } \\
\text { (i.e. one). }\end{array}$ & $\begin{array}{l}\text { s shall be reported under } \\
\text { Normalised results shall } \\
\text { ies a weighting factor }\end{array}$ & $\begin{array}{l}\text { No normalisation: } \\
\text { only includes cl } \\
\text { characterisation. }\end{array}$ & $\begin{array}{l}\text { pact assessment } \\
\text { sification and }\end{array}$ \\
\hline Weighting & $\begin{array}{l}\text { Optional step, if applied: to be reported u } \\
\text { environmental information. }\end{array}$ & der additional & $\begin{array}{l}\text { No weighting: imp } \\
\text { only includes cl } \\
\text { characterisation. }\end{array}$ & $\begin{array}{l}\mathrm{t} \text { assessment } \\
\text { sification and }\end{array}$ \\
\hline \multicolumn{5}{|l|}{ Interpretation of results } \\
\hline & \multicolumn{2}{|c|}{$\begin{array}{l}\text { "Identification of hot-spots" and "Conclusions, limitations and } \\
\text { recommendations" are mandatory. Assessment of the extent to } \\
\text { which methodological choices such as system boundaries, data } \\
\text { sources, and allocation choices influence the analytical outcomes } \\
\text { is mandatory. }\end{array}$} & \multicolumn{2}{|c|}{$\begin{array}{l}\text { No identification of hot-spots nor } \\
\text { recommendations required. }\end{array}$} \\
\hline
\end{tabular}

(2013-2016), as part of the Single Market for Green Products Initiative. The participants in the workshop in Graz and the more detailed comparison in this paper call not only for a harmonisation within a certain programme, but also across programmes including EPDs, PEFs and the CPR $\left(B R 7^{10}\right)$ in order to avoid the current confusion. Construction materials being assessed in the voluntary approaches (EPD and PEF) have to follow the harmonised approach following the principles of the CPR (regulated) not to foster barriers of trade. Such a market partition could help to mainly address the relevant construction materials with high and medium environmental

\footnotetext{
${ }^{10}$ Basic requirement for construction works, no. 7, sustainable use of natural resources - ,use of environmentally compatible raw and secondary materials in the construction works".
}

impacts without further increasing the documentary loads and certification efforts on the business side.

However, the question remains as to whether all these efforts on the material and product assessment level contribute to real lower environmental life cycle impacts. In particular, more robust life cycle inventory data will be required to provide reliable generic data and support the generation of trustworthy environmental declaration.

The LCA community has further been encouraged to increase the meaningfulness of certain impact categories, such as toxicity, land use, biodiversity and resource usage. All authors highly appreciate the most recent activities of CEN/TC 350 WG1 and WG3 currently working on these issues on the standardisation level. A technical report is being developed by CEN TC 350 WG1 and WG3 evaluating impact categories which are currently not included in the EN15804 (and 
EN15978), i.e. human toxicity, ecotoxicity, particulate matter formation, ionising radiation, impacts of land use, biodiversity and water scarcity. Within this technical report, not only the relevance for the environment, construction works, construction products and policy is evaluated but also the scientific substantiation of the available life cycle impact assessment models/methods, the applicability and the stakeholder acceptance. Based on this technical report it, will be decided if any of these additional impact categories will be included in the CEN standards. All these impact categories, except for biodiversity as endpoint indicator, are currently included in the PEF method. If these would hence be added to the CEN standards, this could be an important step in terms of harmonisation of both.

In parallel, if we go towards a more complete list of LICA indicators, harmonisation of background databases would be needed as currently, substantial differences (more than the one found for primary energy or GWP) can be found for some impact categories highly relying on the background database LCI level of details, e.g. toxicity and ecotoxicity (Lesage et al. 2013; Lasvaux et al. 2014b; Lasvaux et al. 2015).

Last but not least, the construction industry and the European Commission are aware of the need for harmonisation between the different environmental claims, especially between the EPDs based on the EN 15804 and the PEFs based on the PEF method. How this harmonisation could be enhanced is being explored in several of the ongoing PEF pilot studies related to construction products. One of the issues focused on in the PEF pilots related to construction products is the relevance of each of the impact categories, the difference in end-of-life approach and the data quality requirements. Both the PEF and EN15804 approach are being applied in the PEF pilots in order to learn from the main differences in the context of harmonising both.

It can be seen that harmonisation efforts are currently still ongoing on different levels, and it seems as if these need better coordination. Finally, the LCA community has further been encouraged to increase the background life cycle inventory data, environmental impact indicators and life cycle inventory modelling, which are considered to be the three most important and significant elements as also stated in the 57th Discussion Forum on LCA (Frischknecht et al. 2015).

\footnotetext{
Acknowledgments The authors would like to extend their thanks to Graz University of Technology for all its financial support on the occasion of the Sustainable Building Conference (Graz SB13) and especially to the organisation team for providing the logistics and a suitable location for the international EPD workshop. In addition to the authors, the following persons whom we would like to thank for their presentations participated in the workshop are Peter Maydl (Graz University of Technology), Gernot Brandweiner (Verband Österreichischer Beton- und Fertigteilwerke/AT) and Rainer Mikulits (Austrian Institute of Construction Engineering/AT). We would also like to thank Guillaume Habert from ETH Zürich/CH and two anonymous reviewers for providing feedback on improving the paper.
}

\section{References}

AFNOR (2004) NF P 01-010, Environmental quality of construction products - environmental and health declaration of construction products, December 2004

AFNOR (2014a) Programme for environmental and health declaration for construction products "Programme FDE\&S", June 2014, 50 p, accessed 27/07/2014: www.afnor.org/content/download/19089/ 142735

AFNOR (2014b) XP P01-064/CN April 2014, Sustainability of construction works - environmental product declarations - core rules for the product category of construction - national addition to NF EN 15804+A1, April 2014

AFNOR (2014c) XP C08-100-1, Environmental declarations for electrical, electronic and HVAC equipment intended for use in building structures - common rules, February 2014

Allacker K (2012) Environmental and economic optimisation of the floor on grade in residential buildings. Int J Life Cycle Assess 17:813827

Baitz M, Albrecht S, Brauner E et al (2012) LCA's theory and practice: like ebony and ivory living in perfect harmony? Int J Life Cycle Assess 18:5-13

Braune A, Wittstock B (2011) Measuring environmental sustainability: the use of LCA based building performance indicators. Life Cycle Manag Conf

BSI (2011) PAS 2050 - specification for the assessment of the life cycle greenhouse gas emissions of goods and services

CEN (2009) EN TR 15941 declarations - methodology and data for generic data

CEN (2010) ÖNORM EN 15643-1 Sustainability of construction works - assessment of buildings, part 1: general framework

CEN (2013) ÖNORM EN 15804/A1-sustainability of construction works-environmental product declarations-core rules for the product category of construction products

CEN (2014) ÖN EN ISO 14025-environmental labels and declarations-type III environmental declarations-principles and procedures

Del Borghi A (2012) LCA and communication: environmental product declaration. Int J Life Cycle Assess 18:293-295

Earls A (2013) How "green" is a product? Growing market for environmentally friendly products creates interest in EPDs and PCRs. Stand News 41:20-21

EC (2011) Regulation (EU) No 305/2011 of the European Parliament and of the Council of 9 March 2011 laying down harmonised conditions for the marketing of construction products (CPR) and repealing Council Directive 89/106/EEC. Off J Eur Union L 88/5:5-43

EC (2013) Commission recommendation of 9 April 2013 on the use of common methods to measure and communicate the life cycle environmental performance of products and organisations. Off $\mathrm{J}$ Eur Union L 124:216

Frischknecht R, Steiner R, Jungbluth N (2009) Methode der ökologischen Knappheit - Ökofaktoren 2006. Umwelt-Wissen Nr. 0906. Bundesamt für Umwelt (BAFU), Bern.

Frischknecht R, Wyss F, Knöpfel SB, Stolz P (2015) Life cycle assessment in the building sector: analytical tools, environmental information and labels. Int J Life Cycle Assess 20:421-425

Haapio A, Viitaniemi P (2008) A critical review of building environmental assessment tools. Environ Impact Assess Rev 28:469-482

HQE (2014) Le projet « Construction HQE Performance », Association HQE, accessed online 06/07/2015: http://assohqe.org/hqe/spip.php? rubrique 10

Hunsager EA, Bach M, Breuer L (2014) An institutional analysis of EPD programs and a global PCR registry. Int J Life Cycle Assess 19:786795 
INIES (2014) Base nationale française de référence sur les impacts environnementaux et sanitaires des produits, équipements et services pour l'évaluation de la performance des ouvrages, accessed 06/03/2015: http://www.base-inies.fr

Ingwersen WW, Stevenson MJ (2012) Can we compare the environmental performance of this product to that one? An update on the development of product category rules and future challenges toward alignment. J Clean Prod 24:102-108

Ingwersen WW, Subramanian V (2013) Guidance for product category rule development: process, outcome, and next steps. Int J Life Cycle Assess 19:532-537. doi:10.1007/s11367-013-0659-0

Ingwersen W, Subramanian V, Schenck R et al (2011) Product category rules alignment workshop, October 4, 2011 in Chicago, IL, USA. Int J Life Cycle Assess 17:258-263

ISO (2007) ISO 21930 - sustainability in building construction-environmental declaration of building products 36

ISO (2012) ISO 14067 — carbon footprint of products - requirements and guidelines for quantification and communication

JORF (2013a) Décret n 2013-1264 du 23 décembre 2013 relatif à la déclaration environnementale de certains produits de construction destinés à un usage dans les ouvrages de bâtiment, Journal Officiel de la République Française, accessed online 06/07/2015: http:// www.legifrance.gouv.fr/affich Texte.do? cidTexte= JORFTEXT000028398471\&implementation

JORF (2013b) Arrêté du 23 décembre 2013 relatif à la déclaration environnementale des produits de construction et de décoration destinés à un usage dans les ouvrages de bâtiment, Journal Officiel de la République Française, accessed online 06/07/2015: http:// www.legifrance.gouv.fr/affich Texte.do?cidTexte= JORFTEXT000028398569

Lasvaux S, Gantner J, Wittstock B, Bazzana M, Schiopu N, Suanders T, Gazulla C, Mundy J-A, Sjöström C, Fullana-i-Palmer P, BarrowWilliams T, Braune A, Anderson J, Lenz K, Takacs Z, Hans J, Chevalier J (2014a) Achieving consistency in life cycle assessment practice within the European construction sector: the role of the EeBGuide InfoHub. Int J Life Cycle Assesss 19:1783-1793

Lasvaux S, Ventura A, Habert G et al (2014b) Linking research activities and their implementation in practice in the construction sector: the LCA Construction 2012 experience. Int J Life Cycle Assess 19:463470

Lasvaux S, Habert G, Peuportier B, Chevalier J (2015) Comparison of generic and product-specific life cycle assessment databases: application to construction materials used in building LCA, accepted for publication. Int J Life Cycle Assess

Lesage P, Boradbent C, Samson R (2013) Choice of background database in constructing cradle-to-gate LCI for public dissemination: case of the worldsteel datasets, LCM2013 International Conference, Gothenburg, August 2013

METL (2014) Site réglementaire des déclarations environnementales des produits de construction, de décoration et des équipements électriques, électroniques et de génie climatique destinés à un usage dans les ouvrages de bâtiment, accessed online 06/07/2015: http:// www.declaration-environnementale.gouv.fr/

Modahl IS, Askham C, Lyng K-A et al (2012) Comparison of two versions of an EPD, using generic and specific data for the foreground system, and some methodological implications. Int J Life Cycle Assess 18:241-251

Nemry F, Uihlein A, Colodel CM et al (2010) Options to reduce the environmental impacts of residential buildings in the European Union - potential and costs. Energy Build 42:976-984

Passer A, Kreiner H, Maydl P (2012) Assessment of the environmental performance of buildings: a critical evaluation of the influence of technical building equipment on residential buildings. Int J Life Cycle Assess 17:1116-1130. doi:10.1007/s11367-012-0435-6

Passer A, Wall J, Kreiner H, Maydl P, Höfler K (2015) Sustainable buildings, construction products and technologies: linking research and construction practice. Int J Life Cycle Assess 20(1):1-8. doi:10. 1007/s11367-014-0820-4

Pelletier N, Allacker K, Pant R, Manfredi S (2014) The European commission organisation environmental footprint method: comparison with other methods, and rationales for key requirements. Int J Life Cycle Assess 19:387-404

Subramanian V, Ingwersen W, Hensler C, Collie H (2012) Comparing product category rules from different programs: learned outcomes towards global alignment. Int $\mathrm{J}$ Life Cycle Assess 17:892-903

Wallhagen M, Glaumann M (2011) Design consequences of differences in building assessment tools: a case study. Build Res Inf 39:16-33

Wallhagen M, Glaumann M, Eriksson O, Westerberg U (2013) Framework for detailed comparison of building environmental assessment tools. 39-60. doi: 10.3390/buildings3010039

WSB14: World SB14 Barcelona Conference; October 28/30th 2014; http://www.wsb14barcelona.org 